\title{
Improving the Students' Self-Confidence and Speaking Ability in the BIPA Class of Universitas PGRI Semarang through Video-Making Projects
}

\section{Meningkatkan Kepercayaan Diri dan Kemampuan Berbicara Siswa BIPA Universitas PGRI Semarang melalui Proyek Pembuatan Video}

\author{
Raden Yusuf Sidiq Budiawan ${ }^{1}$
}

Artikel diterima editor tanggal 5-5-2020, disetujui untuk dipublikasikan tanggal 23-05-2020

Doi: $x x x x x-x x x x x$

\begin{abstract}
Abstrak
Penelitian ini bertujuan untuk meningkatkan kepercayaan diri siswa dan kemampuan berbicara di kelas BIPA Universitas PGRI Semarang melalui proyek pembuatan video. Penelitian ini adalah penelitian deskriptif kualitatif. Penyediaan data dilakukan dengan wawancara, observasi, dan dokumentasi. Data dianalisis dilaksanakan dengan mengumpulkan data, memberi kode data, membandingkan data, membangun interpretasi, dan melaporkan hasil. Selain itu, untuk mengatasi masalah siswa, beberapa upaya dilakukan agar dapat meningkatkan kepercayaan diri dan kemampuan berbicara siswa sebelum pembuatan video, seperti melakukan permainan peran dan simulasi di kelas. Setelah itu, siswa mempraktikkan kemampuan berbicara mereka dalam situasi nyata. Siklus pertama adalah membuat video proyek di sekitar Kota Semarang, sedangkan siklus kedua dilaksanakan di Kota Magelang. Data penelitian ini disajikan dengan metode formal dan informal. Hasil analisis data menunjukkan bahwa proyek pembuatan video mampu 1) meningkatkan kepercayaan diri dan pelafalan siswa secara signifikan; 2) meningkatkan keterampilan bahasa Indonesia siswa, terutama kelancaran, kosa kata, dan akurasi dalam tata bahasa; dan 3) meningkatkan motivasi dan antusiasme siswa yang mendorong siswa untuk belajar bahasa Indonesia dengan lebih baik di kelas BIPA.
\end{abstract}

Kata kunci: BIPA, proyek pembuatan video, kepercayaan diri, kemampuan berbicara

\begin{abstract}
This study aims to improve student confidence and speaking skills in the BIPA University PGRI Semarang class through video making projects. This research is a qualitative descriptive study. The data were provided by interview, observation, and documentation. The data analyzed is carried out by collecting data, coding data, comparing data, constructing interpretations, and reporting results.
\end{abstract}

\footnotetext{
${ }^{1}$ Raden YusufSidiq Budiawan, Universitas PGRI Semarang, r.yusuf.s.b@upgris.ac.id
} 
In addition, to overcome students 'problems, several attempts were made to increase students' confidence and speaking ability before making videos, such as doing role plays and simulations in class. After that, the students practice their speaking skills in real situations. The first cycle is making a video project around the City of Semarang, while the second cycle is carried out in the City of Magelang. This research data is presented by formal and informal methods. The results of the data analysis showed that the video making project was able to 1) significantly increase the student confidence and pron unciation; 2) improve the students' Indonesian language skills, especially fluency, vocabulary, and accuracy in grammar; and 3) increase their motivation and enthusiasm that encourage them to learn Indonesian in BIPA classes well.

Keywords: BIPA, video making project, self-confidence, speaking ability

\section{Introduction}

Nowadays, advance technology, that is now called by industry revolution 4.0 (IR 4.0), has given a big influence to an educational field. IR 4.0 is characterized by an increase in manufacturing digitalization that is driven by four factors: 1) increased data volume, computing power, and connectivity; 2) the emergence of analysis, ability and business intelligence; 3) the occurrence of new forms of interaction between humans and machines; and 4) digital transfer instructions to the physical world, such as robotics and 3D printing (Lee et al in Afrianto, 2018). Related to the influence of IR 4.0 in the educational field in this era, Fisk (2017) says that there are nine trends that st and out in IR 4.0, i.e. personalized learning, free choice learning, project based, field experience, students' ownership, diverse time and place, data interpretation, mentoring will become more important, and exams will completely change. So, it can be said that the education needs to adjust to evolving technological developments in this era.

There is a need to implemented educational technology in Bahasa Indonesia bagi Penutur Asing (BIPA). The BIPA students need to correlate the learning materials to the real world or the students need to know how to implement their knowledge from classroom to the real situation, so that it will lead them to meaningful learning. Horch (2017) underlines some important points that the students need to develop new ways of communicating or to be put in complex situations. Practically, the students need to work in a framework of projects and from there they need to collaborate with their colleagues, with their teachers and with the outside world. Furthermore, the technology is expected can fulfil the learning needs or aid the educational problems.

One of the educational technologies that is easy to be accessed as teaching aids is video. The teaching activity will be more interesting by using video (Mayer and Plass et al in Chau, 2003; Burt in Dundar \& Simpson, 2000). Video activities are divided into two general activities; those are video watching activity and video making activity. Video watching activity uses video as a main media in the teaching learning process, especially for watching activities. In another hand, video making activity uses camera camcorder as a central learning aid. This activity provides opportunities for the students to work cooperatively together in the process of video production with a focus on particular language point. In the educational field, video making activity is usually put in a project work called videomaking project.

The video-making project is a video that is produced by publisher for certain purpose to ease the students in their learning process (Harmer, 2001). In learning activity, video is related to videotaped production or videotape equipment and technology, which support the learning process as a teaching aid (Richards \& Schmidt, 2002). According to Gardner (1994), video making project uses communicative learning approach when the topics, method of delivery, and all of organization aspects can be negotiated between the teacher and students that then will be negotiated to the internal groups of the students. Gardner (1994) outlines the stages of video project implementation. 
BAHASA: JURNAL KEILMUAN PENDIDIKAN BAHASA DAN SASTRA INDONESIA

2020, 2(2), hlm. $44-53$

https://jurnal.ppjb-sip.id/index.php/bahasa

E-ISSN: 2685-4147 | DOI:

The stages are establishing a project that has clear goals, which must be set from the beginning, involving the students to the project organization, choosing the project's topic that should be discussed with the students, stating the target audience, discussing the production details, and explaining how the students benefited will be the important stages.

There are several challenges and problems in teaching Bahasa Indonesia bagi Penutur Asing (BIPA). Based on the observation and test during teaching learning process, the foreign students in Universitas PGRI Semarang in the academic year of 2018/2019 got problems in pronunciation and accuracy of language use. The persistence of their first-language made it worse, especially the students from Malaysia and Thailand. The student from Senegal got problem with her fluency because she had limited vocabulary in Indonesian. Then, the main problem is they are lack of selfconfidence to speak Indonesian language in the real situation. They were prefer to use their firstlanguage in that situation. It made the learning process did not go where it should be. In the language learning, a video making project is one of the alternative solutions to promote the students' selfconfidence in using English (Nikitina, 2010; Chen, 2005; Canning \& Wilson, 2000). It is an instructional approach in a long-term activity by groups of students that focus on the completion of a task for authentic communicative purposes by video production. The use of video making project expectedly can enlarge their opportunities to gain self-confidence and success in language learning because the project will give the students more speaking practice to improve their self-confidence and speaking ability.

Video can be integrated to the English learning as video making project that will give more practice to build the students' self-confidence (Chapelle, Hughes, Skehan in Gromik, 2008; Charge and Giblin, and Marsh in Gardner 1994). Sarosdy (2006) states that one of the advantages of videotechnology that is the ability to record students' performance can be used for feedback or selfevaluation purposes. Cooper in Krhovská (2007) mentions that the video making task will lead the students to find themselves 'doing new things' in English that can provoke genuinely creative and communicative uses of the language. Harmer (2001) also states that the power of creation, which is stimulated by applying video, can give the students' potential opportunity to create something memorable and enjoyable. The activity will reduce their classroom boredom because teacher may conduct it outside the class.

Furthermore, the video-making project can be an alternative problem solving to cope with many problems in the BIPA classroom. In the project, the students will practice to speak in front of the camera in real situation that involves all of the students to the learning activity. The interesting activity will be external motivation to the students to speak and speak in Indonesian, besides enjoying the learning process (see Harmer, 2001:282). Therefore, the students will keep the spirits up in communicating by using Indonesian while building their self-confidence at once. Based on the explanation above, this study is aimed at improving the students' self-confidence and speaking ability in the BIPA class of Universitas PGRI Semarang through video-making projects. The project aimed to address three areas in which students tend to be weak as they attempt to: speaking ability, selfconfidence, and real-world experience. It is expected that the implementation of the video-making project is feasible to be applied in the BIPA class.

\section{Method}

This research is action research conducted in the BIPA class. Kemmis and Taggart in Pardjono (2007:9) define it as the study aimed to improve the quality of education practice by collecting reports of the activities that is done by participants and understanding their implementation with the condition which gives the influence to the implementation. Burns (1999:30) also mentions that action 
research is the way to make improvements in learning process by giving certain treatment involving researchers, teachers, students and other people related to the study. This research aims to get knowledge or information about changes and improvement because the effect of the certain treatment that makes the object changing or improving. Therefore, this kind of research is very good in making the teaching-learning process to be better than before (Elliott, 1992:49).

The research study can be recognized into four different aspects as suggested by Nunan (1989). They are the development features of language learner, interaction in the target language, classroom tasks, and learning strategy. These four phases are meant to form part of ongoing cycle. Then, the phases will provide a basis for further planning and reflection. In this study, the process of the research study can be seen as follows: 1) problems identification (reconnaissance), 2) planning I, 3) action and observation I, 4) reflection I, 5) planning II (revised planning), 6) action and observation II, 7) reflection II. The data collection techniques were qualitative in nature. The data were obtained by interviewing the students, doing the observation during the teaching-learning process and the project in the field including notes and diaries, documenting the videos in the end of each cycle which were uploaded to YouTube. The data were in the form of field notes and interview transcripts. The instruments for collecting the data were observation sheets and field notes, interview guides (structured), a tape recorder, and a camera.

In this study, the data were analyzed in five stages as stated by Burns (1999:154-160). To begin the data analysis, the first stage was assembling the data. In this stage, the data were assembled to be reread in order to state the important points, then showing up the board pattern to compare to see what fits together. The second stage was coding the data, which was used to specify the patterns of the data. Then, the next stage was comparing the data that was applied to see the repetition of the data pattern and the connection of the different data sources. After that, the fourth stage was building interpretations. This stage developed explanation why particular pattern of interaction and attitude had come up in this project. The last stage was reporting the outcomes, which presented the report of the research study to others. The data were also triangulated by analyzing them using the interview transcripts, the experts' theory, and other notes that were related to the data such as notes of the learning process, the students' achievements, and errors during the process. The students' achievements were divided into achievements in speaking skills and selfconfidence assessed by assessment parameter adopted from Weir in Luoma (2004) and Brown (2001) for speaking skills and Barber (2003) and Brown (2001) for self-confidence. Furthermore, this research data is presented by formal and informal methods (Sudaryanto, 2015:241).

\section{Discussion}

The first step of this study is reconnaissance process. It had captured a number of problems in the Bahasa Indonesia bagi Penutur Asing (BIPA) class in Universitas PGRI Semarang in the academic year of 2018/2019. First, the main problem is they are lack of self-confidence to speak Indonesian language in the real situation. They were preferred to use their first-language in that situation. It made the learning process did not go where it should be. Second, the students got problems in pronunciation and accuracy of language use. The persistence of their first-language made it worse, especially the students from Malaysia and Thailand.

They pronounce several words with their first language style, for example the words "mereka" and "karena" that are usually pronounced /mərəka/ and /kərəna/ or /kərana/. They also use "lepas itu" to replace the conjunction "setelah itu" or "sesudah itu". In syntax, the students from Thai usually made mistakes in sentence constructions, for example "saya nama ..." that should be "nama saya ..." or the use "daripada" in the sentence "saya berasal daripada Thailand". Third, the student from Senegal got problem with her fluency because she had limited vocabulary in Indonesian. The last, some students are lack of motivation to study in the classroom. 


\section{The Implementation of the Actions in Cycle I}

The actions of Cycle I were done from September to October 2018. The five stages of planning and teaching video production were applied in the Cycle I. The first stage, which was the getting ready, has been done in three meetings. The students were given the theory of text types, i.e. narration, recount, procedures, describing places, things, and situation. They also learned how to be a reporter and news presenter (host). The simulation was also done in the class and university environments. The second stage, which was the pre-production, used two meetings to watch the samples of video-making project, concept the project, and present the project in front of the class to be discussed. In the results of the discussion, the first video project, namely "Semarang Hebat", was programmed to introduce the relics of the Dutch in Semarang. The students, who acted as presenters, would present events and told the history of Tugu Muda Semarang, and other students would act as reporters, told the history and described conditions of other Dutch relics, such as Lawang Sewu, Semarang Tawang Station, Kota Lama, and Toko Oen.

The third stage, which was the production, was done in November 2018. There shooting processes were done two days in Tugu Muda Semarang, Lawang Sewu, Semarang Tawang Station, Kota Lama, and Toko Oen. The fourth stage, which was the post-production, was conducted in two meetings to do some activities, including video editing, video presentation, and evaluation or reflection. The video was also uploaded to YouTube which can be accessed at https://www.youtube.com/watch?v=OjCXOT45qYA (ISOL UPGRIS -Around Semarang 2018). The last stage, the next step, was discussed after the project done. The teacher and students discussed to determine the step of the project based on the evaluation in order to prepare the next project better.

\section{The Reflection of the Actions in Cycle I}

The reflection would evaluate some actions that followed five stages of planning and teaching video production by Druce and Walker (1985) has been done in the first cycle. It was done based on the observation in the teaching learning process and production process, the field notes, and interview with the students. From the first implementation above, it could be classified into two main results, i.e. success and failures.

The success would be described as follows: First, there was the improvement on the students' self-confidence. Based on the observation of their performance, it can be seen that they used gestures and body language well, maintained eye contact with the camera, showed enthusiasm and interest, and kept concentrating during the performance. In addition, the students who were interviewed also gave the same opinion.

\section{(Interview 1)}

Researcher: Okay.. is there any improvement of their self-confidence after they finished the first project?

Respondent: Oh yeah sure. I found that.

The other students also stated that their self-confidence had improved with such statements as "saya berhasil menemukan rasa percaya diri karena berlatih berkali-kali di depan kamera (I found my self-confidence after trying several times in front of the camera)" and "Berlatih mengatur emosi di depan kamera sehingga bisa percaya diri (I can control my emotion (nervous) in front of the camera so that I got my self-confidence)." Based on the assessment of self-confidence adopted from Barber (2003) and Brown (2001) as showed in the table 1 below, two students are good in their 
performance and the others are fair. The scores in the table show that their self-confidence is good enough.

Table 1

\begin{tabular}{|c|c|c|c|c|}
\hline No. & Students' Name & $\begin{array}{l}\text { Numbers of the } \\
\text { indicators fulfilled }\end{array}$ & \multicolumn{2}{|c|}{ Score } \\
\hline 1 & Tang Yi Ying & 9 & $B$ & Good \\
\hline 2 & Asmanee Duerahing & 6 & $\mathrm{C}$ & Fair \\
\hline 3 & Fatou Diagne & 6 & $\mathrm{C}$ & Fair \\
\hline 4 & Zulkiflee Mama & 7 & $\mathrm{~B}$ & Good \\
\hline
\end{tabular}

The Students' Self-confidence in Cycle I

\begin{tabular}{|c|c|c|c|c|c|c|c|}
\hline \multirow[b]{3}{*}{ No } & \multirow{3}{*}{ Students' Name } & \multicolumn{4}{|c|}{ Score } & \multirow{3}{*}{$\begin{array}{l}\text { Total } \\
\text { Score }\end{array}$} & \multirow{3}{*}{ Criteria } \\
\hline & & \multirow{2}{*}{ Fluency } & \multicolumn{2}{|c|}{ Accuracy } & \multirow{2}{*}{ Vocabulary } & & \\
\hline & & & Grammar & Pronunciation & & & \\
\hline 1 & Tang Yi Ying & 23 & 23 & 21 & 23 & 90 & Excellent \\
\hline 2 & Asmanee Duerahing & 19 & 19 & 19 & 20 & 77 & Good \\
\hline 3 & Fatou Diagne & 20 & 19 & 19 & 20 & 78 & Good \\
\hline 4 & Zulkiflee Mama & 22 & 12 & 12 & 20 & 66 & Fair \\
\hline
\end{tabular}

Table 2

The Students' Speaking Skills in Cycle I

In addition, the students mention that they felt the improvement in their speaking skills. They gave some statements, like "Menambah kosa kata (Enrich my vocabulary)", "Jadi sering berlatih menggunakan bahasa Indonesia (It made me more regular in using Indonesian)", "Pengucapan menjadi lebih baik (My pronunciation was better than before)", and "Terdorong untuk menguasai materi sebelum berhadapan dengan kamera (I was encouraged to master the materials before acting in front of the camera)".

Third, the students understood the theories of being a presenter (host) and reporter including the language functions and the simulation. From the interview with a student, he said that he understood the teacher's explanation about the theories. Based on the interview, the student also said that the practice and simulation help him to understand the materials. Forth, the students understood the concept of the video-making project and applied the instructions well. They also enjoyed this kind of learning activity although this was a complicated and tiring activities. Based on the interview, the student said that she could enjoy the project because it was challenging. The observation also captured that the student looked enthusiastic and happy during the process. They were motivated to give their best performance.

In spite of the success of the first cycle, there were also several failures and problems captured. The failures and problems would be described as follows: First, the students' speaking ability has still insufficiently improved. Despite some improvements in their fluency and vocabulary, their language skills still needed to be improved especially the students' accuracy in grammar and pronunciation. In grammar, some students made mistakes in the sentence construction, for example "Ayo, kita mari bersama makan-makan di Toko Oen.", "Dengan Semarang Tawang bisa berjalanjalan lebih.", "Toko Oen ini berdiri dari orang Cina.", "Es krim moka yang dia kurangkan manis.", etc. 
They also made mistakes in pronunciation, for instance the word "es" pronounced as /ais/, "coklat" pronounced as /t foklət/, "museum" pronounced as/mju:zi:əm/, "stasiun" pronounced as/steifən/.

Second, this project faced several technical problems in the production stage, such as sounding, lighting, shooting techniques, equipment, etc. The major technical problems were the sounding and lighting. The equipment was limited to record the sound well and capture their performance brightly.

\section{The implementation of the Actions in Cycle II}

Based on the reflection of the actions in cycle I, the BIPA students still needed to be improved, especially the students' accuracy in grammar and pronunciation. Therefore, the actions of Cycle II were begun by strengthening the students' speaking skills by more practicing and simulating. There was also outing class to the public places, like in Taman Maerakaca (The Maerakaca Park) and Masjid Agung Jawa Tengah (The Great Mosque of Central Java). The cycle II was done from February to March 2019. The pre-production, used two meetings to watch the video project of the cycle I, concept the project, and discussed everything that needed to be improved, including technical problems in the production stage, such as sounding, lighting, shooting techniques, and equipment. The technical production of this cycle was prepared better than the cycle I.

The second video project, namely "Outing Class Central Java", was programmed to introduce the beauty of nature, culture, history, and culinary in Central Java, especially Magelang. The destinations were Borobudur Temple, Ketep Pass (Volcanology Museum), Kyai Langgeng Park, and Kupat Tahu (Culinary). The third stage, which was the production, was done in March 2019. There shooting processes were done in a day in March 25, 2018. The fourth stage, which was the postproduction, was conducted in two meetings to do some activities, including video editing, video presentation, and evaluation or reflection. The video was also uploaded to YouTube which can be accessed at https://www.youtube.com/watch?v=3LpGyj2e77o (BIPA UPGRIS OUTING CLASS CENTRAL JAVA 2019). This cycle was closed by conducting general evaluation of the first and the second projects.

\section{The Reflection of the Actions in Cycle II}

From the second implementation above, it could be classified into two main results, i.e. success and failures. The success would be described as follows: First, the students' self-confidence significantly improved. Based on the observation, their performance was better than before. The student who was interviewed also gave the same opinion.

(Interview 4)

Researcher: Apakah belajar dengan Proyek Membuat Video membantu Anda meningkatkan rasa percaya diri Anda dalam berbahasa Indonesia di ruang publik? (Did learn with the Video-Making Project help you increase your self-confidence to speak Indonesian in public areas?)

Respondent: $Y a$, tentu. Karena saya malu sebelumnya dan membuat video mendorong saya untuk tidak takut lagi dan percaya bahwa saya dapat melakukan lebih banyak dari yang saya bayangkan. Saya tidak takut lagi untuk berbicara di depan orang-orang. Dan itu juga membantu saya bagaimana cara berinteraksi dengan orang-orang yang belum pernah saya temui sebelumnya. (Yes, of course. Because I was ashamed before and making videos encouraged me not to be afraid anymore and believed that I could do more than I imagined. I am not afraid anymore to speak in front of people. And it also helps me how to interact with people I've never met before). 
The other students also stated that their self-confidence had improved well. Based on the assessment of self-confidence adopted from Barber (2003) and Brown (2001), most of the students were excellent in their self-confidence. The result shows significant improvement of the students' performance.

In addition, the students also mentioned that they felt the improvement in their speaking skills. They gave some statements, like "Karena waktu membuat video, saya harus mengulangi kalimat bahasa Indonesia berkali-kali supaya lebih lancar pengucapannya. (When I was in the shooting process, I had to repeat Indonesian sentences many times to make my pronunciation better)", "Ya, dengan proyek membuat video ini, saya jumpa banyak kosa kata yang baru. (Yes, with the project of making this video, I meet a lot of new vocabulary)", "Karena guru saya mengoreksi saya sebelum kami merekam video sehingga saya tidak banyak melakukan kesalahan tata bahasa. (Because my teacher corrected me before recorded the video, so I didn't make many grammatical mistakes)", and "Ketika saya berbicara dalam bahasa Indonesia salah, dosen dan teman-teman akan membetulkan tata bahasanya. Jadi saya bisa meningkatkan tata bahasa Indonesia dengan melalui proyek membuat video. (When I speak the wrong Indonesian, the lecturer and friends will correct the grammar. So, my grammar is improved by making a video project)".

In spite of the success of the second cycle, there were also little mistakes in grammar and pronunciation that were still noted, i.e. some mistakes in grammar, like "Pada pendapat Jeremy itu rasanya bagaimana?", "Kalau ada masa lain kali saya coba lagi", "Kalau kita lihat ini suasananya ada dengan cuaca yang bagus.", "Pikiran saya di sini kalau yang teman kemari untuk santai-santai oke", and a mistake in pronunciation when the student from Thailand said "bagaimana", he pronounced as /bagaimanə/ like Malay dialects. However, the mistakes have significantly diminished when compared to their appearance in the first cycle. In addition, now, they pronounced the word "museum" correctly.

Based on the reflection of the cycle I and cycle II, there are some findings of this research study. First, there is a significant increase in self-confidence and pronunciation of BIPA students. Based on the interview conducted, all the students said that their self-confidence and pronunciation improved well. The table 5 below also shows that their self-confidence increases. In, cycle II, most of the students are able to perform confidently and pronounce Indonesian words better than before. Second, there is increase in Indonesian language skills, especially fluency, accuracy, and vocabulary of Indonesian language. Based on the interview, most of the students said that their language accuracy, fluency, and vocabulary improved better than the first project. The student from Thai said " $Y a$, dengan proyek membuat video ini, saya jumpa banyak kosa kata yang baru. (Yes, with the project of making this video, I meet a lot of new vocabulary)". It shows their improvements in speaking abilities. The students' accuracy and fluency in the cycle I increase to the "good" and "excellent" level in the cycle II. The students are also able to enrich their vocabulary in the cycle II.

Third, there is increased motivation and enthusiasm in BIPA learning. Based on the interview conducted, the students gave some statements, like "Ya (antusias). Ini peluang untuk belajar di luar ruang kuliah, berinteraksi dengan warga lokal dan mempraktik apa yang telah dipelajari." (Yes (enthusiastic). This is an opportunity to study outside the lecture hall, interact with local residents and practice what has been learned.), " $Y a$, saya sangat senang. Karena ini menjadi salah satu gaya belajar yang baru yang saya bisa belajar di luar ruang kelas. Saya bisa menghargai alam, seni, budaya di tempat wisata dan juga saya bisa belajar berbicara bahasa Indonesia di luar kelas." (Yes, I'm very happy because this has become one of the new learning styles that I can study outside the classroom. I can appreciate nature, art, culture in tourist attractions and also I can learn to speak Indonesian outside the classroom.).

Forth, this video project also encourages students to learn Indonesian better. While interviewed, the students conveyed it by saying " $Y a$, pasti (terdorong untuk belajar lebih baik). Karena (proyek) itu mendorong saya untuk melakukan penelitian dan meningkatkan keterampilan presentasi saya." (Yes, I am sure (compelled to study better) because (the project) encouraged me to 
BAHASA: JURNAL KEILMUAN PENDIDIKAN BAHASA

DAN SASTRA INDONESIA

2020, 2(2), hlm. $44-53$

https://jurnal.ppjb-sip.id/index.php/bahasa

E-ISSN: 2685-4147 | DOI:

do research and improve my presentation skills.), "Ya (terdorong untuk belajar lebih baik). (Proyek Video) ini juga meningkatkan kreativitas semasa belajar Bahasa asing (bahasa Indonesia)." (Yes (driven to learn better). (Video Project) also enhances creativity while learning a foreign language (Indonesian). Fifth, the students also said that they understood the learning materials better than in the classroom by answering "Ya. Karena di kelas lebih banyak tentang teori tetapi saat kami membuat video, kami berlatih dengan kenyataan" (Yes, it is. There was a lot of theory in the classroom but when we make a video, we practice it with reality), "Ya. Ini peluang (belajar yang) baik untuk mempraktik supaya bisa menggunakan ilmu itu dalam kehidupan seharian" (Yes, it is. This is a good (learning) opportunity to practice so that you can use that knowledge in your daily life), " $Y a$, lebih baik. Karena ini mempelajari tempat wisata dengan secara langsung lebih baik daripada belajar melalui teks di kelas." (Yes, it's better because this study of tourist attractions directly is better than learning through texts in class).

Based on the interview and observation, the obstacles during the video projects are memorizing and improving their materials on their performance, finding information, remembering and pronouncing Indonesian difficult words, maintaining focus and concentration in the hot weather, and providing proper filming equipment. There are also several things helped the students in the project, that the teacher helped them to summarize the information, gave good explanations for the materials, and managed the projects well. In addition, the students give suggestions for making video projects better, more thematic and varied effective in managing their time, and being able to interact with people in rural areas.

\section{Conclusion}

This action research study that aimed at improving the students' self-confidence and speaking ability in the BIPA class of Universitas PGRI Semarang through video-making projects, met the conclusion that the projects can be implemented in BIPA class. Based on this study, the projects are able to increase the students' self-confidence. In addition, the projects can improve their speaking ability, including language accuracy (grammar and pronunciation), fluency, and vocabulary. The students' self-confidence and pronunciation are significantly improved. It is also found that these projects are able to increase the students' motivation and enthusiasm which encourage them to learn Indonesian better. Moreover, this study proves that learning in the real situations ease the BIPA students to master the target language, i.e. Indonesian language. It strengthens the theory that video making project will give more practice to build the students' self-confidence (Charge and Giblin, and Marsh in Gardner 1994; Canning \& Wilson, 2000; Chen, 2005; Chapelle, Hughes, Skehan in Gromik, 2008; Nikitina, 2010), reinforce the students' linguistic abilities, developing their own learning capacity (Carmona in Sarosdy, 2006), and optimize the students' motivation in language learning (Harmer, 2001:282; Kees de boot, et. al., 2005: 201).

\section{References}

Afrianto. (2018). "Being a Professional Teacher in the Era of Industrial Revolution 4.0: Opportunities, Challenges and Strategies for Innovative Classroom Practices". ELTAR Journal Vol. 2, No.1 Desember 2018.

Barber, H. (2003). Psychology: Motivation; Anxiety; Confidence; Goal-setting. United State. 
Brown, H. D. (2001). Teaching by Principles, an Interactive Approach to Language Pedagogy. Second edition. White Plains: Pearson Education.

Burns, Anne. (1999). Collaborative Action Research for English Language Teaching. Cambridge: Cambridge University Press.

Canning, C. \& Wilson. (2000). "TESL Journal: Practical Aspects of Using Video in the Foreign Language Classroom". The Internet TESL Journal, Vol. VI, No. 11, November 2000 retrieved from http://iteslj.org/Articles/Canning-Video.html on June 11, 2018 at 10 p.m.

Chau, E. (2003). "Developing beginner language skills through video". NSW AMES: AMEP Conference.

Chen, D. (2005). Learn Chinese through Producing Video Clips. New Jersey: Seton Hall University Press.

Druce, M. \& Walker, B. (1985). The Student Video Productions Handbook: a Guide to planning and teaching Student Video production. Alaska: Educational Resources Information Center (ERIC).

Dündar, D. \& Simpson, A. (2000). "To DVD or not to DVD - Is that the Question?". Retrieved from http://www. developingteachers.com/articles.htm on December 20, 2018 at 4 p.m.

Elliot, J. (1991). Action Research for Educational Change, Developing Teachers \& Teaching Series. Buckingham: Open University Press.

Fisk, Peter. (2017). "Education 4.0: The Future of Learning Will be Dramatically Different, in School and Throughout Life". Retrieved from https://www.thegeniusworks.com/2017/01/futureeducation-young-every one-taught-together/ in July 20, 2019 at 9 p.m.

Gardner, D. (1994). Student-Produced Video Documentary: Hong Kong as a Self-Access Resources. Hong Kong: University of Hong Kong.

Gromik, N. (2008). "Windows Movie Maker in the English as a Foreign Language Class". Retrieved from http://www.innovateonline.info/ on June 10, 2018 at 11 p.m.

Harmer, J. (2001). The Practice of English language Teaching. Edinburg: Pearson Education Limited.

Horch, D. (2017). "Industry 4.0 and Its Impact on Education". Retrieved from https://restartproject.eu/industry-4-0-impact-education/ in July 20, 2019 at 7 p.m.

Kees de boot, et. al. (2005). Second language acquisition: an Advance Resource Book. New York.

Krhovská, M. (2007). "New Ways of Teaching Cultural Studies". Masaryk University in Brno, Faculty of Education. Retrieved from http://is.muni.cz/th/79822/pedf_m/New_Ways_of_Teaching_Cultural_St Studies on November 28, 2018 at 8 a.m.

Luoma, Sari. (2004). Assessing Speaking. Cambridge: Cambridge University Press.

Nikitina, L. (2010). "Video-Making in the Foreign Language Classroom: Applying Principles of Constructivist Pedagogy". Electronic Journal of Foreign Language Teaching 2010, Vol. 7, No. 1, pp. 21-31 (c) Centre for Language Studies National University of Singapore.

Nunan, D. (1989). Understanding Language Classrooms: A Guide for Teacher-Initiated Action. New York, NY: Prentice Hall.

Pardjono, et. al. (2007). Panduan Penelitian Tindakan Kelas. Yogyakarta: Lembaga Penelitian UNY.

Richards, J. \& Schmidt, R. (2002). Longman Dictionary of language Teaching \& Applied Linguistics. British: Pearson education.

Sarosdy, J. et.al. (2006). "Applied Linguistics I for BA Students in English". Retrieved from http://mek.oszk. hu/05300/05323/05323.pdf on December 27, 2018 at 8.50 p.m.

Sudaryanto. (2015). Metode dan Aneka Teknik Analisis Bahasa. Yogyakarta: Duta Wacana University Press. 